GRASAS Y ACEITES $72(1)$

January-March 2021, e395

ISSN-L: 0017-3495

https://doi.org/10.3989/gya.0100201

\title{
Impact of plum processing on the quality and oxidative stability of cold-pressed kernel oil
}

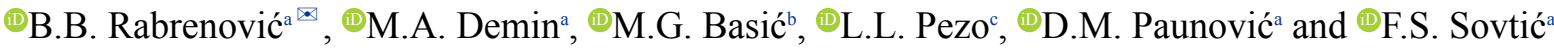 \\ ${ }^{a}$ Faculty of Agriculture, University of Belgrade, Nemanjina 6, Belgrade 11080, Serbia \\ bInstitute of Mother and Child Healthcare of Serbia "Dr Vukan Čupić", Belgrade, 11070, Serbia \\ 'Institute of General and Physical Chemistry, P. O. Box 45, Belgrade 118 11158, Serbia \\ ${ }^{\bowtie}$ Corresponding author: biljanar@agrif.bg.ac.rs
}

Submitted: January 03, 2020; Accepted: February 11, 2020; Published online: March 3, 2021

\begin{abstract}
SUMMARY: Plum kernels of the "Čačanska rodna" variety, by-products from plum brandy production, were collected before and after fermentation and distillation, and used for cold-pressed oil production. Fatty acid and tocopherol contents were determined by capillary GC and HPLC, while the oxidation stability of the resulting cold-pressed oils was tested by the Rancimat method. The results showed that oleic fatty acid was dominant in the oil samples with a content of 56.6 to $61.8 \%$, regardless of the plum kernels' origin. The fermentation and distillation processes had a pronounced effect on the tocopherol content and oxidative stability of the resulting kernel oils. Tocopherol contents were $61.8 \mathrm{mg} \cdot 100 \mathrm{~g}^{-1}, 87.4 \mathrm{mg} \cdot 100 \mathrm{~g}^{-1}, 79.6 \mathrm{mg} \cdot 100 \mathrm{~g}^{-1}$ of oil, while the induction periods were $38.7,44.4$ and 33.6 hours for samples before fermentation, after fermentation and distillation, respectively. Based on the results, it could be concluded that the fermentation process increased the content of tocopherols in kernel oil whereas the high temperature during the distillation process adversely affected the tocopherol content and oxidative stability of the obtained kernel oil.
\end{abstract}

KEYWORDS: By-product; Cold-pressing; Fatty acids; Oxidative stability; Plum kernels; Tocopherols

RESUMEN: Impacto del procesamiento de ciruelas en la calidad y la estabilidad oxidativa del aceite del hueso prensado en frío. Los huesos de ciruelas de la variedad "Čačanska rodna", subproductos de la producción de brandy de ciruela, se procesaron antes y después de la fermentación y la destilación, y se utilizaron para la producción de aceite prensado en frío. El contenido de ácidos grasos y tocoferoles se determinó mediante GC capilar y HPLC, mientras que la estabilidad oxidativa de los aceites prensados en frío resultantes se determinó mediante el método Rancimat. Los resultados obtenidos mostraron que el ácido oleico era predominante en los aceites, con un contenido de 56,6 a 61,8\%, independientemente del origen de los huesos de las ciruelas. Los procesos de fermentación y destilación tuvieron un efecto pronunciado sobre el contenido de tocoferoles y sobre la estabilidad oxidativa de los aceites de hueso resultantes. El contenido de tocoferoles fue de $61,8 \mathrm{mg} \cdot 100 \mathrm{~g}^{-1}, 87,4 \mathrm{mg} \cdot 100 \mathrm{~g}^{-1}, 79,6 \mathrm{mg} \cdot 100 \mathrm{~g}^{-1}$ de aceite, mientras que los períodos de inducción fueron de 38,7, 44,4 y 33,6 horas para las muestras antes de la fermentación, después de la fermentación y la destilación, respectivamente. En base a los resultados obtenidos, se podría concluir que el proceso de fermentación aumentó el contenido de tocoferoles en el aceite de hueso, mientras que la alta temperatura durante el proceso de destilación afectó negativamente al contenido de tocoferoles y la estabilidad oxidativa del aceite de hueso obtenido.

PALABRAS CLAVE: Ácidos grasos; Estabilidad oxidativa; Huesos de ciruela; Prensado en frío; Subproducto; Tocoferoles

Citation/Cómo citar este artículo: Rabrenović BB, Demin MA, Basić MG, Pezo LL, Paunović MD, Sovtić FS. 2021. Impact of plum processing on the quality and oxidative stability of cold-pressed kernel oil. Grasas Aceites 72 (1), e395. https://oi.org/10.3989/ gya.0100201

Copyright: (C2021 CSIC. This is an open-access article distributed under the terms of the Creative Commons Attribution 4.0 International (CC BY 4.0) License. 


\section{INTRODUCTION}

Plum is the leading fruit species grown in Serbia and, in some ways, a symbol of Serbia. It has been grown in this region for centuries, thanks to several advantages: it reproduces relatively easily, starts bearing fruit fast and thrives in hilly and mountainous regions, where it represents $70 \%$ of the total fruit species. Serbia is the third plum producer in the world, with 500,000 tons annually, ranking below China with six million tons and India, with 600,000 tons per year (Mratinić, 2013). In Serbia, most of the plum yield, $90 \%$, is processed into plum brandy, with the remaining fruit processed into jam, compote, preserves and a significant portion dried. Plum processing yields pomace, skins and pits as by-products. Pomace and skins are a valuable source of phenolic compounds, while pits are usually used as fuel or disposed of as waste. Pits represent 9 to $11 \%$ of the weight of plum fruits, while the kernels represent 17 to $20 \%$ of the weight of pits, depending on the plum variety. Bearing in mind that the average plum yield in Serbia is about $7 \mathrm{t} \cdot \mathrm{ha}^{-1}$, according to the records of the National Office for Statistics, it can be concluded that about $700 \mathrm{~kg} \cdot \mathrm{ha}^{-1}$ of plum pits are produced as byproducts.

According to the FAO data for 2000-2009, plum orchards in Serbia covered 191,021 ha, which leads to the conclusion that 1,300 tons of plum pits, i.e. 230 tons of kernels, remain as byproducts. The kernel is high in oil content; the content varies and depends on both phenotypic and genotypic factors, but according to the literature, it can exceed 40\% (Kamel and Kakuda, 1992; Uluata and Nurhayat, 2017). Such a high oil content makes plum kernel an excellent raw material for the production of cold-pressed oil, with all nutritionally valuable oil components preserved, since, as described by Codex Standard, "Cold-pressed oils are obtained, without altering the oil, by mechanical procedures only, e.g. expelling or pressing, without the application of heat. They may have been purified by washing with water, settling, filtering and centrifuging only. (CX-STAN 210 - 1999, Vol. 8). In addition to its favorable fat content, which is dominated by monounsaturated oleic acid and polyunsaturated linoleic acid, omega- 6 fatty acid, plum kernel oil has a relatively high content in tocopherols with $\gamma$-tocopherol as its major component, which contributes to the excellent oxidative stability of this oil (Kamel and Kakuda, 1992; Picuric-
Jovanovic et al., 1997; Özcan et al., 2014; Górnaś et al., 2017a).

There is insufficient data in the literature on cold-pressed plum kernel oil, or on the impact of raw material processing on the quality of the obtained oil. Since most of the plum in Serbia is processed into plum brandy ("šljivovica" eng. slivovitz), many changes (thermal, oxidative and hydrolytic) occurring during fermentation and distillation can affect the nutritional quality of the cold-pressed oil. The objective of this study was to examine the quality and oxidative stability of cold-pressed plum kernel oil derived from different stages of plum brandy production.

\section{MATERIALS AND METHODS}

\subsection{Material}

Kernels of the plum variety "Čačanska rodna" were used as starting material for the production of cold-pressed oil. Kernels from fresh plums before fermentation (PKBF) were used, as well as those extracted from different stages of the slivovitz production process, in particular, kernels separated after fermentation (PKAF) and kernels separated after distillation (PKAD). Plums were allowed to ferment for 13 days at $18-20^{\circ} \mathrm{C}$, while batch distillation was performed in a traditional alembic pot of $250 \mathrm{~L}$ for 3 hours by direct heating. In the beginning, distillation was induced by strong heating, which was continued for a short period after the condensed distillate began to trickle. Depending on the alcohol-to-water ratio, the mixture boils between 78.5 and $100{ }^{\circ} \mathrm{C}$.

Once the pits were cracked open in a nutcracker with rotating cylinders, the released kernels were dried on paper, in a thin layer, at ambient temperature $\left(22-24{ }^{\circ} \mathrm{C}\right)$ for $72 \mathrm{~h}$, with occasional manual stirring. The kernels were dried to $6 \%$ humidity to facilitate cold-pressing.

\subsection{Cold-pressing}

The kernels (approximately 300 g per sample) were cold-pressed in a small-scale screw oil press (Gorenje, $2 \mathrm{~kg} \cdot \mathrm{h}^{-1}$ capacity, power $650 \mathrm{~W}$ ). The temperature of the obtained oil was monitored by an IC thermometer and kept below $45^{\circ} \mathrm{C}$.

After cold-pressing, the oils were kept at room temperature $\left(22-24{ }^{\circ} \mathrm{C}\right)$ for 24 hours for natural sedimentation and then decanted. The oil samples were stored in dark glass bottles in a refrigerator at $4{ }^{\circ} \mathrm{C}$ until analysis (within 2 weeks). 


\subsection{Determination of peroxide and acid value}

\subsubsection{Peroxide value}

The peroxide value (PV), expressed in $\mathrm{mmol} \cdot \mathrm{kg}^{-1}$, was determined according to SRPS EN ISO 660:2015. The determination was carried out in triplicate.

\subsubsection{Acid value}

The acid value $(\mathrm{AV})$, expressed in $\mathrm{mg} \mathrm{KOH} \cdot \mathrm{g}^{-1}$, was determined according to SRPS EN ISO 3960:2016. The determination weas carried out in triplicate.

\subsection{Determination of fatty acid composition}

Fatty acid methyl esters (FAME's) were prepared using the standard method according to ISO E. 5509 (2000). FAME's were determined according to the gas chromatography method described by SRPS EN ISO 12966-4 (2016) by capillary gas chromatography on Agilent Technologies 6890 (USA) GC device equipped with split/splitless injector, flame ionization detector (FID) and capillary column Supelco SP-2560 (length $100 \mathrm{~m}$, i.d. $0.25 \mathrm{~mm}$, film thickness $0.20 \mu \mathrm{m}$, Supelco, Bellefonte, USA). Injector and detector temperatures were 250 and $260{ }^{\circ} \mathrm{C}$, respectively. Helium was used as the carrier gas at a flow rate of $5 \mathrm{~mL} \cdot \mathrm{min}^{-1}$. The injected volume was $1 \mu \mathrm{L}$ and the injector split ratio was set at 20:1. The column temperature was programmed from the initial $50{ }^{\circ} \mathrm{C}$ (held $5 \mathrm{~min}$ ) to $240{ }^{\circ} \mathrm{C}$ (held $20 \mathrm{~min}$ ), with a temperature rate of $4{ }^{\circ} \mathrm{C} \cdot \mathrm{min}^{-1}$. The chromatographic peaks in the samples were identified by comparing the relative retention times of FAME peaks with peaks in Supelco 37 Component FAME mix standard (Supelco, Bellefonte, USA). Total fatty acids were calculated in $\mathrm{mg} \cdot \mathrm{g}^{-1}$ of lipids and individual fatty acids were expressed in relative quantities as mass $\%$ of total fatty acids.

\subsubsection{Indexes of lipid nutritional quality (INQ)}

The nutritional quality of the lipid fraction of samples was determined by examining the fatty acid profile and taking into consideration two indexes: atherogenicity (AI) and thrombogenicity (TI) (Ulbricht and Southgate, 1991).

$$
(\mathrm{AI})=[(4 \times \mathrm{C} 14: 0)+\mathrm{C} 16: 0+\mathrm{C} 18: 0] / \Sigma \mathrm{MUFA}+\Sigma \mathrm{PUFA}
$$

$$
\begin{gathered}
(\mathrm{TI})=(\mathrm{C} 14: 0+\mathrm{C} 16: 0+\mathrm{C} 18: 0) / \\
(0.5 \mathrm{MUFA}+0.5 \text { PUFA }-\mathrm{n} 6+3 \text { PUFAn } 3+ \\
\text { PUFA }-\mathrm{n} 3 / \text { PUFA - n6 })
\end{gathered}
$$

Where

MUFA - monounsaturated fatty acid

PUFA - polyunsaturated fatty acid

\subsection{Determination of tocopherols}

The determination of tocopherols was carried out using HPLC (Waters M600E, USA) on a reverse-phase Nucleosil 50-5 C18 column (Machery-Nagel, Germany) with fluorescence detection according to a method based on the procedure of Carpenter (1979) with some modifications. The following procedures were applied: $20 \mathrm{~mL}$ of $96 \% \mathrm{v} / \mathrm{v}$ of ethanol, $0.12 \mathrm{~g}$ of pyrogallol, and $3 \mathrm{~mL} \mathrm{KOH}$ solution were added to $0.5 \mathrm{~mL}$ of oil, after which the solution was heated for $30 \mathrm{~min}$ at $60^{\circ} \mathrm{C}$ with reflux and stirring.

Once the saponification process was completed, the content was cooled, transferred to a volumetric flask $(50 \mathrm{~mL})$ and topped with ethanol. An aliquot of $5 \mathrm{~mL}$ was then transferred to a separation funnel and $5 \mathrm{~mL}$ of cold deionized water and $5 \mathrm{~mL}$ of hexane were added. The mixture was vortexed for $3 \mathrm{~min}$ and $4 \mathrm{~mL}$ of the solution were dried under a nitrogen blanket. The dry matter was then dissolved in $4 \mathrm{~mL}$ of methanol. The sample was filtered using a membrane syringe filter and injected into the HPLC system. The mobile phase was $95 \% \mathrm{v} / \mathrm{v}$ methanol at a flow rate of $1.2 \mathrm{~mL} \cdot \mathrm{min}^{-1}$. Detection was performed by a fluorescence detector (Shimadzu RF-535, Japan) operated with the excitation wavelength at $\lambda=290 \mathrm{~nm}$ and the emission wavelength at $\lambda=330 \mathrm{~nm}$. The relative retention time and maximum values of absorption at the given relative retention time were used for the identification of tocopherols in the oil samples.

Commercial tocopherol standards were suitably diluted and used for method validation (solution series from 0.001 to $0.5 \mu \mathrm{g} \cdot \mathrm{mL}^{-1}$ ), and for quantification purposes (solution series from 0.05 to $\left.10.0 \mu \mathrm{g} \cdot \mathrm{mL}^{-1}\right)$. Total time of the chromatographic analysis was 20 minutes. The signal was processed using "Clarify" software. 
Furthermore, the tocopherol content was calculated based on a comparative analysis of peaks of standards and samples. According to Table 1, the method is sufficiently sensitive and specific for determining the acceptable levels of tocopherols.

\subsection{Oxidative stability determination}

\subsubsection{Rancimat test}

The oxidative stability of the samples was determined on a Rancimat apparatus model 743 (Metrohm, Herisau, Switzerland) according to ISO 6886:2016. Oil samples $(2.5 \mathrm{~g})$ were transferred to reaction vessels. The samples were heated at $100{ }^{\circ} \mathrm{C}$, with an airflow of $20 \mathrm{~L} \cdot \mathrm{min}^{-1}$. The volatile components released during oxidation were collected in a cell with water, and the increase in electrical conductivity of the water was constantly measured and recorded over a period of time. In this way, the induction period, IP (h), was determined, which shows the oil's resistance to oxidation.

\subsection{Statistical analysis}

All determinations were carried out in triplicate and values were expressed as a mean of three measurements \pm standard deviation. Statistical analysis was performed using the StatSoft Statistica 10 software (StatSoft, Inc. STATISTICA, ver. 10, data analysis software system). To test the mean differences, a variance analysis (one-way ANOVA) was performed, followed by the Tukey's HSD test at the significance level of $\mathrm{p}<0.05$.

\section{RESULTS AND DISCUSSION}

\subsection{Peroxide and acid values}

The basic chemical quality of the oil was examined by determining the peroxide and acid values (Table 2). These two parameters are very important as they indicate the condition and quality of the oil.

TABLE 2. Peroxide and acid values

\begin{tabular}{ccc}
\hline Sample & PV $\left(\mathbf{m m o l} \cdot \mathbf{~ k g}^{-1}\right)$ & AV $\left(\mathbf{m g K O H} \cdot \mathbf{g}^{-1}\right)$ \\
\hline PKBF & $0.0 \pm 0.0^{\mathrm{a}}$ & $0.2 \pm 0.0^{\mathrm{a}}$ \\
PKAF & $0.9 \pm 0.1^{\mathrm{b}}$ & $3.4 \pm 0.3^{\mathrm{b}}$ \\
PKAD & $4.3 \pm 0.4^{\mathrm{c}}$ & $3.7 \pm 0.3^{\mathrm{b}}$ \\
\hline
\end{tabular}

"The results are presented as mean value $\pm \mathrm{SD}(\mathrm{n}=3)$; different letters in columns indicate that there is significant difference at $\mathrm{p}<0.05$, (according to Tukey's HSD test).

PV - Peroxide Value, AV - Acid value. PKBF - Kernels from fresh plums before fermentation, PKAF - Kernels separated after fermentation, PKAD - kernels separated after distillation.

The peroxide value of edible oils is an important indicator of quality and the values obtained were far below the upper limit values prescribed by the Codex Alimentarius Commission (El-Adawy and Taha, 2001). Oil samples from fresh and fermented kernels were found to have peroxide values of $0.0 \mathrm{mmol} \cdot \mathrm{kg}^{-1}$ and $0.9 \mathrm{mmol} \cdot \mathrm{kg}^{-1}$, respectively, showing that the oil had not been oxidized, i. e. that there had not been any changes in the contents in primary oxidation products during fermentation.

However, even though the peroxide value of oil from kernels that had been distilled was within the limits acceptable to the Codex Alimentarius Commission (El-Adawy and Taha, 2001), a significantly higher value was found, $4.3 \mathrm{mmol} \cdot \mathrm{kg}^{-1}$, indicating that the higher temperatures during distillation had affected oxidative processes and the kernel oil quality.

As for acid value, fresh plum kernel oil showed the lowest value, $0.2 \mathrm{mg} \mathrm{KOH} \cdot \mathrm{g}^{-1}$, while the highest value was found in the oil from the kernels of distilled pits, $3.7 \mathrm{mg} \mathrm{KOH} \cdot \mathrm{g}^{-1}$. The oil produced from fermented kernels had an acid value of $3.4 \mathrm{mg} \mathrm{KOH} \cdot \mathrm{g}^{-1}$. The obtained values were expected since fresh plum kernels had not been processed in any way, and the oil had been pressed immediately after pit cracking;

TABLE 1. Analytical performance of the method based on HPLC with fluorescence detection

\begin{tabular}{|c|c|c|c|c|c|c|}
\hline Tocopherols & Linearity & Calibration range $(\mathrm{n}=6)\left(\mu \mathrm{g} \cdot \mathrm{mL}^{-1}\right)$ & $\operatorname{LOD}\left(\mu \mathrm{g} \cdot \mathrm{mL}^{-1}\right)$ & $\operatorname{LOQ}\left(\mu \mathrm{g} \cdot \mathbf{m L}^{-1}\right)$ & Recovery $(\%)$ at level of $1 \mu \mathrm{g} \cdot \mathrm{mL}^{-1}$ & RSD (\%) \\
\hline$\alpha$ & 0.9995 & $0.05-10.0$ & 0.007 & 0.03 & 98.1 & 1.90 \\
\hline$\beta+\gamma$ & 0.9998 & $0.05-10.0$ & 0.006 & 0.02 & 97.7 & 1.98 \\
\hline$\delta$ & 0.9999 & $0.05-10.0$ & 0.006 & 0.02 & 98.4 & 1.09 \\
\hline
\end{tabular}

"LOD - Limit of Detection; LOQ - Limit of Quantitation; RSD - Relative Standard Deviation 
conversely, triacylglycerols were hydrolyzed in the presence of water, heat and certain microflora during fermentation and distillation. Dulf et al., (2016) also concluded that there was an increase in free fatty acids during solid-state fermentation of plum pomace (from the juice industry) and brandy distillery wastes, due to hydrolysis and the presence of lipid-degrading enzymes.

\subsection{Fatty acid composition}

When considering the biologically active components of edible oils, fatty acid composition and content are of particular significance. In addition to providing the highest amount of energy, certain fatty acids are essential for the normal functioning of the body; they can even have a protective effect from various health conditions. Table 3 presents the composition of fatty acids in the examined oil samples derived from the kernels of damson plums var. "Čačanska rodna" from plum kernels before fermentation (PKBF), plum kernels after fermentation (PKAF) and plum kernels after distillation (PKAD).

TABLE 3. Fatty acids (FA) and indexes of atherogenicity (AI) and thrombogenicity (TI)

\begin{tabular}{lccc}
\hline FA $\left(\mathbf{g} \cdot \mathbf{1 0 0 g}^{-1}\right)$ & PKBF & PKAF & PKAD \\
\hline C16:0 & $5.3 \pm 0.6^{\mathrm{b}}$ & $5.6 \pm 0.9^{\mathrm{b}}$ & $5.4 \pm 0.9^{\mathrm{c}}$ \\
C16:1 & $1.4 \pm 0.6^{\mathrm{a}}$ & $1.5 \pm 0.4^{\mathrm{a}}$ & $1.5 \pm 0.5^{\mathrm{a}}$ \\
C18:0 & $1.6 \pm 0.4^{\mathrm{a}}$ & $1.7 \pm 0.3^{\mathrm{a}}$ & $1.6 \pm 0.5^{\mathrm{a}}$ \\
C18:1 cis & $61.8 \pm 1.1^{\mathrm{d}}$ & $61.6 \pm 1.4^{\mathrm{d}}$ & $56.5 \pm 2.0^{\mathrm{f}}$ \\
C18:1 trans & - & - & $3.1 \pm 0.2^{\mathrm{b}}$ \\
C18:2 cis & $29.9 \pm 1.3^{\mathrm{c}}$ & $29.6 \pm 0.9^{\mathrm{c}}$ & $29.1 \pm 1.1^{\mathrm{e}}$ \\
C18:2 trans & - & - & $2.8 \pm 0.6^{\mathrm{b}}$ \\
$\Sigma$ SFA & $6.9 \pm 1.1^{\mathrm{b}}$ & $7.3 \pm 1.2^{\mathrm{b}}$ & $7.0 \pm 1.4^{\mathrm{d}}$ \\
$\Sigma$ MUFA & $63.2 \pm 1.7^{\mathrm{d}}$ & $63.1 \pm 1.8^{\mathrm{d}}$ & $59.6 \pm 2.7^{\mathrm{f}}$ \\
LPUFA & $29.9 \pm 1.3^{\mathrm{c}}$ & $29.6 \pm 0.9^{\mathrm{c}}$ & $31.9 \pm 1.7^{\mathrm{e}}$ \\
O/L & 2.1 & 2.1 & 1.9 \\
AI & 0.07 & 0.08 & 0.08 \\
TI & 0.15 & 0.16 & 0.16 \\
\hline
\end{tabular}

Oleic acid was found to be dominant in all samples, with 55.7-63.2\%. It was followed by linoleic $(27.0-29.9 \%)$, palmitic $(5.3-5.6 \%)$ and stearic acids (1.6-1.7\%). The obtained data are in line with the results reported by other authors (Hassanein, 1999; Özcan et al., 2014; Uluata and Nurhayat, 2017; Górnaś et al., 2017a). In terms of fatty acid content, especially when it comes to the dominant monounsaturated oleic acid, plum kernel oil resembles olive oil and as such has a significant nutritional value. In addition, the linoleic fatty acid content is also very important, since this is an essential $\omega-6$ fatty acid, necessary for the formation of cell membranes, vitamin D metabolism and synthesis of various hormones (Simopoulos, 2002). Also, the oleic/linoleic acid ratio $(\mathrm{O} / \mathrm{L}$ ratio $)$ is a significant indicator of the quality of kernels and oils of the genus Prunus. The higher the $\mathrm{O} / \mathrm{L}$ ratio, the better the quality and oxidative stability of the kernels and oil. In the examined samples, this ratio was in the range of 1.9-2.1. By comparison, the $\mathrm{O} / \mathrm{L}$ ratio ranged from 2.20-4.97 in 20 almond selections examined by Čolić et al., (2017).

Palmitoleic acid was also detected in oils from kernels that had undergone fermentation and distillation, representing 1.5 and $1.4 \%$, respectively. Even though the three examined oils showed very similar fatty acid compositions, there was a difference in presence and content in trans fatty acids in oils originating from kernels that had passed through distillation. Since the distillation was carried out in an alembic pot directly heated by a wood-fuelled fire, we assume that the lower layers of the fruit mash (containing the majority of pits) were occasionally overheated in the absence of intense stirring, which may have caused the isomerization of double bonds and the appearance of trans fatty acids. Such a high content in trans fatty acids (5.9\%) is not desirable and it decreases the nutritional value of the oil derived from distilled kernels.

The range of different fatty acid types in the examined kernel oils was as follows: saturated (6.9-7.3\%), monounsaturated (59.6-63.2\%) and polyunsaturated (29.6-31.9\%). MUFA-containing oils are more stable and less susceptible to oxidation than those containing PUFAs. Also, several studies have shown that MUFAs increased HDL cholesterol and decreased both total and LDL cholesterol, lowered blood pressure, improving circulation by reducing clogging and hardening of arteries (Mariotti and Peri, 2014).

The atherogenicity and thrombogenicity indexes are indicators of cardiovascular disease risk increase and are related to fatty acid composition. Given the predominant monounsaturated oleic fatty acids in plum kernel oil, these indices have low values in the examined samples (AI 0.07-0.08 and TI 0.15-0.16), indicating that the oil lowers the risk of cardiovascular disease and is, therefore, healthier. 


\subsection{Tocopherol content and composition}

Tocopherols are essential unsaponifiable components of vegetable oils. The total content of these natural antioxidants, as well as the presence of some of their homologues, depend on multiple factors (raw material variety, type of oil, climate conditions, oil production process, tocopherol measurement methods, etc). There are four tocopherol homologues: $\alpha-, \quad \beta-, \quad \gamma-$ and $\delta$ tocopherol; $\alpha$-tocopherol increases the biological value of vegetable oils while $\gamma$ - and $\delta$-tocopherols increase oxidative stability. $\beta$-tocopherol is seldom found in vegetable oils (Pongracz et al., 1995; Kamal-Eldin, 2006). The content and composition of tocopherols in the examined oils are shown in Table 4.

TABLE 4. Content and composition of tocopherols $\left(\mathrm{mg} \cdot 100 \mathrm{~g}^{-1}\right)$

\begin{tabular}{ccccc}
\hline Sample & $\boldsymbol{\alpha}$-tocoferol & $\boldsymbol{\beta}+\boldsymbol{\gamma}$-tocoferol & $\boldsymbol{\delta}$-tocoferol & $\begin{array}{c}\text { Total } \\
\text { tocopherols }\end{array}$ \\
\hline PKBF & $7.0 \pm 0.2^{\mathrm{a}}$ & $48.5 \pm 0.8^{\mathrm{a}}$ & $6.3 \pm 0.4^{\mathrm{a}}$ & $61.8 \pm 1.4^{\mathrm{a}}$ \\
PKAF & $18.6 \pm 0.6^{\mathrm{c}}$ & $57.7 \pm 1.3^{\mathrm{b}}$ & $11.1 \pm 0.7^{\mathrm{c}}$ & $87.4 \pm 2.6^{\mathrm{c}}$ \\
PKAD & $15.0 \pm 1.1^{\mathrm{b}}$ & $56.4 \pm 0.9^{\mathrm{b}}$ & $8.2 \pm 1.1^{\mathrm{b}}$ & $79.6 \pm 3.1^{\mathrm{b}}$ \\
\hline
\end{tabular}

"The results are presented as mean value \pm SD $(n=3)$; different letters in columns indicate that there is significant difference at $\mathrm{p}<0.05$, (according to Tukey's HSD test).

PKBF - Kernels from fresh plums before fermentation, PKAF Kernels separated after fermentation, PKAD - kernels separated after distillation.

As can be seen in Table 4, the lowest total tocopherol content was in the oil from PKBF, $61.8 \mathrm{mg} \cdot 100 \mathrm{~g}^{-1}$ while the total tocopherol content was significantly higher in the oil after fermentation $\left(87.4 \mathrm{mg} \cdot 100 \mathrm{~g}^{-1}\right)$ and distillation $\left(79.6 \mathrm{mg} \cdot 100 \mathrm{~g}^{-1}\right)$. The increase in tocopherol content can be explained by the effect of alcohol during the fermentation process, which accelerates the separation of individual components, affecting primarily the porosity of the kernel. However, during distillation, although this process may continue, high temperatures cause degradation of the tocopherols and decrease their content (Bjelica et al., 2019). The $\beta+\gamma-$ tocopherol were dominant in all oil samples, with $48.5 \mathrm{mg} \cdot 100 \mathrm{~g}^{-1}$ in PKBF, while in oil samples from PKAF and PKAD, this tocopherol homologues were represented by 57.7 and $56.4 \mathrm{mg} \cdot 100 \mathrm{~g}^{-1}$, respectively. According to the literature, the remaining representatives of the Prunus genus also have $\gamma$-tocopherol as the dominant tocopherol in their kernel oils, with its content ranging up to $1333 \mathrm{mg} \cdot \mathrm{kg}^{-1}$, which was found in sour cherry kernel oil (Matthaus and Özcan, 2009; Manzooret al., 2012; Górnaś et al., 2016b; Górnaś et al., 2017b).

The content of $\delta$-tocopherol, the homologue that greatly increases oxidative stability, is particularly interesting. The highest content in this homologue was found in the oil from kernels after fermentation, $11.1 \mathrm{mg} \cdot 100 \mathrm{~g}^{-1}$. The content of $\alpha$-tocopherol ranged from $7.0 \mathrm{mg} \cdot 100 \mathrm{~g}^{-1}$ in oil from PKBF to $18.6 \mathrm{mg} \cdot 100 \mathrm{~g}^{-1}$ in PKAF and $15.0 \mathrm{mg} \cdot 100 \mathrm{~g}^{-1}$ in PKAD oil. The results are comparable to the results for $\alpha$ - and $\gamma$-tocopherol content found by Górnaś et al., (2015) in their analysis of the composition of tocochromanols in the kernels of 28 different plum varieties. However, the $\delta$-tocopherol content in the samples analyzed by Górnaś et al., (2015) was far lower, ranging from 0.71 to $4.04 \mathrm{mg} \cdot 100 \mathrm{~g}^{-1}$. In further investigations, Górnaś et al., (2016a) found the content of total tocochromanols for 28 different plum varieties to be quite high, in a wide range of 70.7-208.7 mg $\cdot 100 \mathrm{~g}^{-1}$ oil.

Even though the plum kernel oil can be compared to olive oil in terms of its fatty acid composition and content, this is not the case when it comes to tocopherol content. $\alpha$-tocopherol is dominant in olive oil, ranging up to $370 \mathrm{mg} \cdot \mathrm{kg}^{-1}$ in content (Psomiadou et al., 2000). In terms of tocopherol content and composition, this oil can be compared to maize, soy and rapeseed oils (Moreau, 2002).

\subsection{Oxidative stability}

When determining the quality of cold-pressed oils, another important parameter is oxidative stability, i.e. the preservation of oil from oxidation over a certain period of time. Oxidative stability was tested using the Rancimat test based on IP in hours. The results are shown in Table 5.

The results of the IP determination show a very good oxidative stability of the examined oils. The highest IP was found in the PKBF sample, $44.4 \mathrm{~h}$, with the oxidative stability decreasing after fermentation and distillation, so the IP in the PKAF and PKAD samples was found to be $38.7 \mathrm{~h}$ and $33.6 \mathrm{~h}$, respectively. Comparing the obtained results using the Tukey test $(p<0.05)$ shows that there is a statistically significant difference in the induction period between oil samples from kernels before and after treatments (fermentation, distillation). 
TABLE 5. Oxidative stability

\begin{tabular}{cc}
\hline Sample & IP (h) $\mathbf{1 0 0}{ }^{\circ} \mathbf{C}, \mathbf{2 0} \mathbf{L} \cdot \mathbf{h}^{-1}$ \\
\hline PKBF & $38.7 \pm 1.9^{\mathrm{b}}$ \\
PKAF & $44.4 \pm 1.7^{\mathrm{c}}$ \\
PKAD & $33.6 \pm 1.2^{\mathrm{a}}$
\end{tabular}

$\overline{{ }^{7}}$ The results are presented as mean value $\pm \mathrm{SD}(\mathrm{n}=3)$; different letters in the column indicate that there is significant difference at $\mathrm{p}<0.05$, (according to Tukey's HSD test).

IP - induction period. PKBF - Kernels from fresh plums before fermentation, PKAF - Kernels separated after fermentation, PKAD - kernels separated after distillation.

There is insufficient data on the IP of coldpressed plum kernel oil in literature. Uluata and Nurhayat (2017) listed an IP of $15.1 \mathrm{~h}$ for plum kernel oil, without specifying whether this oil was cold-pressed; the Rancimat test was performed at a slightly higher temperature $\left(110^{\circ} \mathrm{C}\right)$. The same authors listed IP values for sour cherry kernel oil, another plant from the Prunus genus, of only $1.5 \mathrm{~h}$ (Uluata and Nurhayat, 2017). Uluata (2016) compared IPs (Rancimat test at $110^{\circ} \mathrm{C}$ ) of apricot kernel oil obtained by two methods, cold pressing and solvent extraction. The solvent-extracted oil showed a longer induction period $(20.1 \mathrm{~h})$ than the cold-pressed $(15.1 \mathrm{~h})$. Comparing oxidative stability of cold-pressed plum kernel oil and apricot kernel oil during thermal and photooxidation, Kiralan et al., (2018) found plum kernel oil to be more stable than apricot kernel oil.

Such high oxidative stability of the tested samples is probably due to the predominant MUFA and total tocopherols, but other bioactive components not covered by this research could have certainly contributed.

\section{CONCLUSIONS}

Plum kernels are a good material for coldpressed oil production, bearing in mind the total oil content. The oils from kernels obtained before and following fermentation and distillation vary in terms of fatty acid composition, tocopherol content and oxidative stability. Trans fatty acids were detected in the oil from kernels obtained after distillation. This was the oil sample with the lowest tocopherol content and the lowest oxidative stability; therefore, plum kernels obtained after distillation of the mash are not recommended for the production of cold-pressed oil.

\section{ACKNOWLEDGMENTS}

This work was supported by the Serbian Ministry of Education and Science, projects TR 46010 and 31006.

\section{REFERENCES}

Bjelica M, Vujasinović V, Rabrenović B, Dimić, S. 2019. Some chemical characteristics and oxidative stability of cold pressed grape seed oils obtained from different winery waste. Eur. J. Lipid Sci. Technol. 121, 1800416. https://doi.org/ 10.1002/ejlt.201800416

Čolić S, Fotirić Akšić M, Lazarević K, Zec G, Gašić U, Dabić Zagorac D, Natić, M. 2017. Fatty acid and phenolic profiles of almond grown in Serbia. Food Chem. 234, 455-463. https://doi.org/10. 1016/j.foodchem.2017.05.00 6

Dulf FV, Vodnar DC, Socaciu, C. 2016. Effects of solid-state fermentation with two filamentous fungi on the total phenolic contents, flavonoids, antioxidant activities and lipid fractions of plum fruit (Prunus domestica L.) by-products. Food Chem. 209, 27-36. https://doi.org/10.1016/j.foo dchem.2016.04.016

El-Adawy TA, Taha KM. 2001. Characteristic and composition of different seed oils and flours. Food Chem. 74, 47-54. https://doi.org/10.1021/ jf001117+

Górnaś P, Rudzińska M, Soliven A. 2017a. Industrial by-products of plum Prunus domestica L. and Prunus cerasifera Ehrh. as potential biodiesel feedstock: Impact of variety. Ind. Crops Prod. 100, 77-84. https://doi.org/10.1016/j.ind crop.2017.02.014

Górnaś P, Radziejewska-Kubzdela E, Mišina I, Biegańska-Marecik R, Grygier, A, Rudzińska M. 2017b. Tocopherols, tocotrienols and carotenoids in kernel oils recovered from 15 apricot (Prunus armeniaca L.) genotypes. J. Am. Oil Chem. Soc. 94, 693-699. https://doi.org/10.1007/s11746-0172978-y

Górnaś P, Rudzińska M, Raczyk M, Mišina I, Soliven A, Lacis, G, Seglina D. 2016a. Impact of species and variety on concentrations of minor lipophilic bioactive compounds in oils recovered from plum kernels. J. Agric. Food Chem. 64, 898-905. https://doi.org/10.1021/acs.jafc.5b053 30

Górnaś P, Rudzińska M, Raczyk M, Mišina I, Soliven A, Seglina D. 2016b. Composition of bioactive compounds in kernel oils recovered 
from sour cherry (Prunus cerasus L.) byproducts: Impact of the cultivar on potential applications. Ind. Crops Prod. 82, 44-50. https:// doi.org/10.1016/j.indcrop.2015.12.010

Górnaś P, Grāvīte I, Mišina I, Lacis G, Radenkovs V, Olšteine A, Seglina D, Kaufmane E, Rubauskis E. 2015. Composition of tocochromanols in the kernels recovered from plum pits: the impact of the varieties and species on the potential utility value for industrial application. Eur. Food Res. Technol. 24, 513-520. https://doi.org/10.1007/s00217- 015-2480-4

Hassanein M. 1999. Studies on non-traditional oil: Detailed studies on different lipid profiles of some Rosaceae kernel oils. Grasas Aceites 5, 379-384. https://doi.org/10.3989/gya.1999.v50.i5. 682

ISO. 2000. International Standards Official Methods 5509:2000. Animal and Vegetable Fats and OilsPreparation of methyl esters of fatty acids. International Organization for Standardization, Geneve, Switzerland.

ISO. 2016. International Standards Official Methods 6886:2016 - Animal and Vegetable Fats and Oils -Determination of Oxidative Stability (Accelerated Oxidation Test). International Organization for Standardization, Geneve, Switzerland.

Kamal-Eldin A. 2006. Effect of fatty acids and tocopherols on the oxidative stability of vegetable oils. Eur. J. Lipid Sci. Technol. 58, 1051-1061. https://doi.org/10.1002/ejlt.2006000 90

Kamel BS, Kakuda Y. 1992. Characterization of the seed oil and meal from apricot, cherry, nectarine, peach and plum. J. Am. Oil Chem. Soc. 69, 492-494. https://doi.org/10.1007/BF0 2540957

Kiralan M, Kayahan M, Kiralan SS, Ramadan M F. 2018. Effect of thermal and photooxidation on the stability of cold-pressed plum and apricot kernel oils. Eur. Food Res. Technol. 244, 31-42. https://doi.org/10.1007/s00217-0 17-2932-0

Manzoor M, Anwar F, Ashraf M, Alkharfy KM. 2012. Physico-chemical characteristics of seed oils extracted from different apricot (Prunus armeniaca L.) varieties from Pakistan. Grasas Aceites 63, 193-201. https://doi.org/10.3989/gya. 095011

Mariotti M, Peri C. 2014. The composition and nutritional properties of extra-virgin olive oil, in Peri C (Ed.) The extra-virgin olive oil handbook. John Wiley \& Sons, Oxford, UK.

Matthaus B, Özcan MM. 2009. Fatty acids and tocopherol contents of some Prunus spp. kernel oils. J. Food Lipids 16, 187-199. https://doi.org/ 10.1111/j.1745-4522.2009.01140.x

Moreau RA, Whitaker BD, Hicks KB. 2002. Phytosterols, phytostanols, and their conjugates in foods: structural diversity, quantitative analysis, and health-promoting uses. Prog. Lipid Res. 41, 457-500. https://doi.org/10.1016/S0163 -7827(02)00006-1

Mratinić E. 2013. Šljiva, Partenon, Beograd. (in Serbian)

Özcan MM, Ünver A, Arslan D. 2014. A research on evaluation of some fruit kernels and/or seeds as a raw material of vegetable oil industry. Qual. Accur. Saf. Crop. Foods 7, 187-191. https:// doi.org/10.3920/QAS2013.0319

Picuric-Jovanovic K, Vrbaski Z, Milovanovic M. 1997. Aqueous enzymatic extraction of plum kernel oil. Fett/Lipid 99, 433-435. https://doi.org/ 10.1002/lipi.19970991205

Pongracz G, Weiser H, Matzinger D. 1995. Tocopherol-Antioxidantien der Natur. Fett/Lipid 97, 90-104. https://doi.org/10.1002/lipi.1995097 0303

Psomiadou E, Tsimidou M, Boscou D. 2000. Alphatocopherol content of Greek virgin olive oils. $J$. Agric. Food Chem. 48, 1770-5. https://doi.org/ 10.1021/jf990993o

Simopoulos AP. 2002. The importance of the ratio of omega-6/omega-3 essential fatty acids. Biomed. Pharmacother. 56, 365-379. https:// doi.org/10.1016/S0753-3322(02)00253-6

SRPS EN ISO 660:2015 - Animal and vegetable fats and oils - Determination of acid value and acidity. Institute for Standardization of Serbia.

SRPS EN ISO 3960:2016 - Animal and vegetable fats and oils - Determination of peroxide value

SRPS EN ISO 12966-4:2016 - Gas chromatography of fatty acid methyl esters - Part 4: Determination by capillary gas chromatography. Institute for Standardization of Serbia.

Ulbricht TLV, Southgate DAT. 1991. Coronary heart disease: Seven dietary factors. Lancet 338, 985-992. https://doi.org/10.1016/0140-6736(91) 91846-M

Uluata S, Özdemir N. 2017. Evaluation of chemical characterization, antioxidant activity and oxidative stability of some waste seed oil. Turkish J. Agric. Food Sci. Technol. 5, 48-53. https://doi.org/10.24925/turjaf.v5i1.48-53.909

Uluata S. 2016. Effect of extraction method on biochemical properties and oxidative stability of apricot seed oil. Academic Food J. 14, 333-340. 